\title{
Effects of a cyclopoid copepod (Diacyclops thomasi) on phytoplankton and the microbial food web
}

\author{
Dean R. Dobberfuhl*, Rich Miller, James J. Elser \\ Dept of Zoology, Arizona State University, Tempe, Arizona 85287, USA
}

\begin{abstract}
A plankton community unconditioned by Diacyclops thomasi predation was incubated with and without $D$. thomasi for $10 \mathrm{~d}$ to test the hypothesis that a recent manipulation of the food web of Castle Lake, CA; USA, altered phytoplankton biomass and productivity via effects of cyclopoid predation on microconsumers. Microconsumer grazing rates on bacteria and phytoplankton, ciliate abundance, chlorophyll, phytoplankton biovolume, and bacterial abundance were quantified before and after incubation. $D$. thomasi significantly reduced ciliate abundances relative to controls lacking $D$. thomasi. D. thomasi treatments also had higher chlorophyll concentration, bacterial abundance and maximum growth capacity of phytoplankton relative to controls. These results are consistent with the hypothesis that increases in D. thomasi in Castle Lake following food web manipulation affected limnological processes by affecting microconsumer abundances with subsequent effects on algae and bacteria
\end{abstract}

KEY WORDS: Diacyclops thomasi Cyclopoid Microconsumer grazing · Phytoplankton - Bacteria

\section{INTRODUCTION}

In September of 1989, a whole-lake food web manipulation was initiated in Castle Lake, an oligotrophic subalpine lake in California, USA (Elser et al. 1995). Stocking of rainbow trout Oncorhynchus mykiss, the dominant planktivore, was discontinued for a period of 3 yr. Following the theory of Cascading Trophic Interactions (Carpenter et al. 1985), removal of planktivorous fingerling trout should enhance Daphnia populations and reduce phytoplankton biomass. However, after the manipulation primary productivity (PPr) increased and Secchi depth decreased (Elser et al. 1995). These phytoplankton responses were accompanied by changes in the zooplankton community. Specifically, Diacyclops thomasi, a predatory cyclopoid virtually absent prior to manipulation, became the dominant zooplankter throughout most of the summer following the manipulation. Daphnia dentifera, the dominant herbivore, maintained its pre-manipulation biomass for the first year following the manipulation

·E-mail: dean.dobberfuhl@asu.edu and then slowly declined. However, changes in water quality preceded any changes in the Daphnia biomass. Thus, changes in water quality appeared to be due to trophic interactions other than herbivorous macrozooplankton grazing (Elser et al. 1995).

Elser et al. (1995) hypothesized that the dramatic increase in Diacyclops thomasi indirectly affected water quality via increased $D$. thomasi predation on microconsumers. In particular, they suggested that increased predation pressure by $D$. thomasi on microconsumers such as ciliates reduced the intensity of grazing on phytoplankton, resulting in increased phytoplankton biomass and PPr. Previous studies are consistent with this hypothesis. For example, calanoid copepods have been shown to significantly reduce microconsumers such as ciliates in both marine (Jonsson \& Tiselius 1990, Stoecker \& Capuzzo 1990) and freshwater systems (Burns \& Gilbert 1993, Hartmann et al. 1993). Much of this work indicates that the feeding rate of calanoid copepods on ciliates is comparable to or higher than their feeding rates on algae or nanoplankton (Stoecker \& Capuzzo 1990, Hartmann et al. 1993). It follows that cyclopoid copepods, which are raptorial feeders in later copepodite and adult stages, 
should also affect ciliates. The few studies that have been performed indicate that cyclopoid effects on ciliates are generally large and negative (Archbold \& Berger 1985, Brett et al. 1994, Wiackowski et al. 1994 . Wickham 1995a) but cyclopoid effects on ciliates can be affected by prey behavior, morphology, and the presence of alternative prey items (Stemberger 1985 , Wickham 1995b).

Predation-driven changes in ciliate abundance also appear to be propagated to lower trophic levels. For example, ciliate abundance and composition have been shown to strongly affect heterotrophic flagellates and bacteria (Sanders \& Wickham 1993, Sanders et al. 1994) as well as phytoplankton (Beaver \& Crisman 1990) in certain systems. As lakes become more oligotrophic along a trophic gradient, mean ciliate size tends to increase (Beaver \& Crisman 1989, 1990). Since larger ciliates are generally phytophagous in oligotrophic systems like Castle Lake, predation-driven changes in ciliate populations may affect phytoplankton community structure and dynamics.

During the summer of 1993 an experiment was performed to test the hypothesis of Elser et al. (1995) that increased primary productivity and decreased water clarity following the food web manipulation in Castle Lake resulted from effects of Diacyclops thomasi predation on microconsumers, thus altering the grazing rate on phytoplankton and bacteria. We wanted to determine whether increased densities of $D$. thomasi would increase predation on ciliates and decrease ciliate abundances in a plankton community unconditioned by $D$. thomasi, such as was likely the case in Castle Lake prior to the rise in $D$. thomasi documented by Elser et al. (1995). Furthermore, we predicted that decreased ciliate abundances would lead to increases in phytoplankton biomass and bacterial abundance compared to control treatments due to lowered microconsumer grazing.

\section{METHODS}

Study sites. Castle Lake is a moderately large (20 ha), deep (mean depth $11.4 \mathrm{~m}$, maximum depth $35 \mathrm{~m}$ ) lake located at an elevation of $1657 \mathrm{~m}$ in the Siskiyou Mountains in northern California. Nutrient dynamics and primary productivity have been monitored continuously since 1959 (Goldman \& De Amezaga 1984). The lake is oligotrophic with a Secchi depth of $-11 \mathrm{~m}$ and an annual range in chlorophyll (chl) concentration of 1 to $5 \mu \mathrm{g} \mathrm{l^{-1 }}$. Spring blooms are dominated by diatoms and other chrysophytes, while dinoflagellates, gelatinous green and blue-green algae, and small flagellates dominate in the summer (Janik 1988, Elser 1992). Microzooplankton ( $<83 \mu \mathrm{m}$ ) consist of heterotrophic flagellates, small rotifers (Synchaeta pectinata, Keratella cochlearis, Gastropus stylifer), and ciliates (Urotricha farcta, Stobilidium sp., Cyclidium sp., and others). Macrozooplankton species include Daphnia dentifera, Holopedium gibberum, Diacyclops thomasi, Bosmina longirostris, and Diaptomus novamexicanus (Wiackowski et al. 1994).

Rather than using Castle Lake water and its Diacyclops thomasi-conditioned plankton community, we chose to use plankton from nearby Cliff Lake for our experiments. Cliff Lake is also an oligotrophic (1 to $5 \mu \mathrm{g}$ chl a $\mathrm{I}^{-1}$ ) glacial cirque lake (5 ha) with similar water clarity (14 $\mathrm{m}$ Secchi depth). We wished to assess the likely effects of $D$. thomasi on plankton unaccustomed to $D$. thomasi predation (i.e. similar to Castle Lake prior to $D$. thomasi's increase). The plankton assemblage in nearby Cliff Lake had only 0.1 to $1.0 \mathrm{D}$. thomasi $1^{-\dagger}$ and we assumed that Cliff Lake's plankton community structure and trophic status were similar to those of Castle Lake before manipulation, although few data are available to test this assumption. If the ideas of Elser et al. (1995) regarding the limnological effects of $D$. thomasi were correct, we anticipated that introductions of $D$. thomasi into the Cliff Lake plankton community, unconditioned by cyclopoid predation, would result in changes similar to those in Castle Lake following manipulation.

Mesocosm experiment. The experiment was begun by taking multiple net tows in Castle Lake to collect Diacyclops thomasi that were then hand-picked into 5 aliquots of $\sim 150$ copepods each. At the time of collection most $D$. thomasi were late stage copepodites (IV+) and adults (D. Dobberfuhl pers. obs.). Late stage copepodites of $D$. thomasi were considered to be carnivorous (Carter 1974) although later studies indicated cyclopoids can be omnivorous (Adrian 1991, Santer 1993). Aliquots were kept cool and dark overnight. A volume of $100 \mathrm{l}$ of epilimnetic water from Cliff Lake was screened through $83 \mu \mathrm{m}$ Nitex mesh to remove metazoans and transported to Castle Lake. Triplicate samples for chl analysis (using GF/F filters), ciliate, rotifer, and phytoplankton enumeration (preserved with Lugol's solution) and duplicate samples for bacterial enumeration (preserved with filtered formaldehyde to a final concentration of $2 \%$ ) were taken. Rotifers were virtually absent in water collected from cubitainers after the $10 \mathrm{~d}$ incubation $\left(<0.02 \mathrm{I}^{-1}\right)$; therefore, no data will be presented. Phytoplankton and ciliates were enumerated by settling and counting a $50 \mathrm{ml}$ sample using an inverted microscope. A dilution gradient experiment to assess initial microconsumer herbivory and bacterivory rates was also initiated (see design below).

Eight 10 I translucent cubitainers were then filled with screened Cliff Lake water. Diacyclops thomasi 
were rinsed and 1 aliquot with 150 individuals was added to each of 4 cubitainers while the other 4 remained as controls. The fifth aliquot was preserved with Lugol's for later verification of stage. A density of 15 ind. $1^{-1}$ represents average ambient density of adult D. thomasi in the epilimnion of Castle Lake during summer stratification (Brett et al. 1994, Elser et al. 1995). Cubitainers were placed on an incubation rack and incubated in Castle Lake at $2.5 \mathrm{~m}$ and $14^{\circ} \mathrm{C}$ for $10 \mathrm{~d}$, a period that we felt was long enough to observe both direct and indirect effects of $D$. thomasi on algal and microbial community structure. The rack was shaken twice daily.

Following the $10 \mathrm{~d}$ incubation, water from each cubitainer was screened through $83 \mu \mathrm{m}$ Nitex to collect macrozooplankton for immediate assessment of Diacyclops thomasi survivorship and for later enumeration of all macrozooplankton. Duplicate chl filters, a $500 \mathrm{ml}$ ciliate and rotifer sample preserved with Lugol's solution, and a phytoplankton sample preserved with Lugol's solution were prepared from each cubitainer Phytoplankton samples were enumerated and used to calculate total biovolume as well as a biovolumeweighted average phytoplankter volume $\left(P V, \mu \mathrm{m}^{3}\right.$ cell ${ }^{-1}$ ) to assess mean phytoplankton community size. $\mathrm{PV}$ is calculated using the equation

$$
P V=\left[\sum\left(b_{i} \times m_{i}\right)\right] / B
$$

where $b_{i}$ is the biovolume of species $i_{1} m_{i}$ is the average cell biovolume of species $i$, and $B$ is the total phytoplankton biovolume. Finally, nutrient-enriched dilution gradient experiments were initiated for assessment of microconsumer herbivory and bacterivory rates in each cubitainer (see below).

Dilution gradient experiments. To determine rates of microconsumer herbivory and bacterivory prior to and after Diacyclops thomasi additions, we used dilution gradient experiments (Landry \& Hassett 1982, as modificd by Elser \& Frees 1995). Initial Cliff Lake water and water from each cubitainer at the end of the incubation was used to make a series of dilutions $(0.05 x, 0.2 x, 0.4 x$, and $0.8 x$, where $x$ is the fraction of whole-lake water) of $83 \mu \mathrm{m}$ screened sample water with $0.2 \mu \mathrm{m}$ filtered water according to the approach of Landry \& Hassett (1982). To saturate bacterial and algal growth rates during incubation, $\mathrm{N}$ (as $\mathrm{NH}_{4} \mathrm{Cl}$ ) and $\mathrm{P}$ (as $\mathrm{NaH}_{2} \mathrm{PO}_{4}$ ) were added to raise concentrations to 30 and $3 \mu \mathrm{M}$, respectively. Water from each dilution level was placed into triplicate $250 \mathrm{ml}$ clear PVC bottles and incubated in Castle Lake at the depth of $50 \%$ light penetration. After $24 \mathrm{~h}$, bacterial samples were taken from each bottle, preserved as before, and the bottles were returned to the lake. After an additional $24 \mathrm{~h}$, the remaining water in the bottles was filtered through GF/F filters for chl a analysis. Chl a was ana- lyzed using the fluorometric technique (Parsons et al. 1984) after methanol extraction (Marker et al. 1980). Bacteria were enumerated using epifluorescence microscopy (Hobbie et al. 1977).

For the initial sample and for each enclosure, we attempted to calculate microconsumer herbivory and bacterivory rates, as well as maximum growth potential of phytoplankton and bacteria, by regressing specific growth rates $(\mu)$ of chl a or bacteria against degree of dilution with the $y$-intercept an estimate of $\mu_{\max }$ and the slope an estimate of specific grazing rate (Landry \& Hassett 1982). However, the Landry-Hassett analysis assumes that prey densities are below the incipient limiting concentration (ILC). When prey densities are greater than the ILC, non-linearities in the $\mu$ versus $x$ relationship occur and results must be analyzed taking predators' functional response into account (Elser \& Frees 1995). Our results commonly indicated non-linearities and so we estimated maximum growth capacities of phytoplankton and bacteria using growth rate data from the 2 lowest dilutions $(0.05 x$ and $0.2 x)$ and extrapolating the $y$-intercept. The grazing rate in the initial sample and in each cubitainer was then estimated as the difference between estimated maximum growth capacity ( $y$ intercept) and observed net growth rate in the least diluted sample $(0.8 x)$. Data from Diacyclops thomasi and control treatments were compared using Student's $t$-test of means.

\section{RESULTS}

Mean $( \pm 1 \mathrm{SE})$ recovery of living Diacyclops thomasi was $92.3 \pm 2.4$, which represents a mean survivorship of $\sim 70 \%$ (based on 129 copepods added, estimated from the preserved aliquot). Most dead $D$. thomasi did not appear to be extensively decomposed, suggesting that most mortality occurred at the end of the experiment or that mortality was caused by sample handling in terminating the incubation. Since handling produced minimal mortality when the experiment was started, age or food limitation may have been responsible for mortality late in the experiment. This degree of mortality is similar to other studies that have used D. thomasi (Brett et al. 1994. Wiackowski et al. 1994).

Total ciliate abundances were strongly reduced $(50 \%)$ in Diacyclops thomasi treatments relative to controls ( $p=0.03$; Table 1 ). Abundances of 7 of the 9 ciliate species were lower in $D$. thomasi treatments relative to controls, suggesting that most ciliate taxa present were affected by $D$. thomasi (Table 1). Four species in particular were affected by $D$. thomasi: Mesodinium sp. and Strobilidium sp. were signifi- 
Table 1 Individual ciliate biovolume and abundances before and after incubation with (w/) and without (w/o) Diacyclops thomasi. Asterisks indicate the results of student's $t$-test between treatments with and without $D$. thomasi ( $p<0.05)$. Where zeros appear for abundances, species were not detected

\begin{tabular}{|c|c|c|c|c|c|c|c|}
\hline \multirow{2}{*}{$\begin{array}{l}\text { Species } \\
\text { Cyclidium sp. }\end{array}$} & \multirow{2}{*}{$\begin{array}{c}\begin{array}{c}\text { Biovolume } \\
\left(\mathrm{mm}^{3} \mathrm{cell}^{-1}\right)\end{array} \\
404\end{array}$} & \multicolumn{2}{|c|}{ Initıal } & \multicolumn{3}{|c|}{ Abundance $\mathrm{m}^{-1}( \pm 1 \mathrm{SE})$} & al w/ \\
\hline & & 0.54 & $(0.15)$ & 0.80 & $(0.30)$ & 0.61 & $(0.09)$ \\
\hline Cyrtolophosis sp. & 1300 & 0.00 & $(0.00)$ & 0.12 & $(0.04)$ & 0.05 & $(0.05)$ \\
\hline Pelagostrombidium sp. & 3424 & 0.00 & $(0.00)$ & 0.03 & $(0.03)$ & 0.01 & $(0.01)$ \\
\hline Mesodinium sp. & 5000 & 0.11 & $(0.11)$ & 1.45 & $(0.17)$ & 0.42 & $(0.08)^{\circ}$ \\
\hline Urotricha farcta & 5060 & 0.36 & $(0.07)$ & 5.89 & $(1.23)$ & 3.45 & $(0.60)$ \\
\hline Halteria sp. & 5270 & 0.01 & $(0.01)$ & 0.00 & $(0.00)$ & 0.05 & $(0.05)$ \\
\hline Askenasia sp & 11500 & 0.00 & $(0.00)$ & 0.04 & $(0.01)$ & 0.06 & $\{0.02\}$ \\
\hline Strombidium viridae & 17700 & 0.00 & $(0.00)$ & 0.39 & $(0.10)$ & 0.19 & $(0.04)$ \\
\hline Strobilidium sp. & 22500 & 1.33 & $(0.29)$ & 0.93 & $(0.23)$ & 0.36 & $(0.12)^{*}$ \\
\hline Total & & 2.37 & $(0.42)$ & 9.64 & (1.85) & 5.23 & $(0.68)^{\circ}$ \\
\hline
\end{tabular}

cantly reduced in abundance in the $D$. thomasi treatments $(\mathrm{p}<0.001$ and $\mathrm{p}=0.03$, respectively) while reductions in Urotricha farcta and Strombidium viridae were marginally significant $(p=0.06)$. While not statistically significant, Cyclidium sp., Cyrtolophosis sp., and Pelagostrombidium sp. were also reduced by 25 to $60 \%$ (Table 1). These results demonstrate that cyclopoid predation can decrease ciliate abundances in an unconditioned plankton community. Furthermore, all ciliates affected by addition of $D$. thomasi have been shown to ingest bacteria as well as larger particles (i.e. algae or other protozoans; K. Wiackowski pers. comm.). So, changes in abundances of ciliate prey items would also be expected.

Dilution gradient experiments indicated that microconsumer herbivory rates were slightly higher in treatments with Diacyclops thomasi, but this difference was not statistically significant (Table $2 ; \mathrm{p}=$ 0.09). However, chl a was nearly $50 \%$ lower in the absence than in the presence of $D$. thomasi $(p=0.05$; Table 2). Phytoplankton biomass, as estimated by phytoplankton biovolume, was significantly higher in treatments with $D$. thomasi than in controls (Table 3 ).

Table 2. Mean ( $\pm 1 \mathrm{SE}$ ) community parameters at the end of the $10 \mathrm{~d}$ incubation with (w/) and without (w/o) Diacyclops thomasi. Grazing and growth rates were generated from the Landry-Hassett experimental component. Chl $a$, bacterial abundance, and $P V$ (phytoplankter volume) were directly measured. $p<0.05$ using a Student's t-test of means

\begin{tabular}{|lcccc|}
\hline & w/o D. thomasi & w/ D. thomasi \\
\hline Grazing rate on phytoplankton $\left(\mathrm{d}^{-1}\right)$ & $0.24(0.03)$ & $0.32(0.04)$ \\
Grazing rate on bacteria $\left(\mathrm{d}^{-1}\right)$ & 2.24 & $(0.12)$ & $2.36(0.16)$ \\
Chl a $\left(\mu \mathrm{g} \mathrm{I}^{-1}\right)$ & 2.24 & $(0.23)$ & $4.30(1.04)^{\circ}$ \\
Phytoplankton growth rate $\left(\mathrm{d}^{-1}\right)$ & $0.33(0.02)$ & $0.51(0.04)^{*}$ \\
Bacterial abundance $\left(\times 10^{6} \mathrm{ml}^{-1}\right)$ & $3.05(0.06)$ & $4.42(0.00)^{\circ}$ \\
Bacterial. growth rate $\left(\mathrm{d}^{-1}\right)$ & $2.50(0.22)$ & $2.40(0.16)$ \\
PV $\left(\mu^{3} \mathrm{~m}^{3}\right.$ cell $\left.{ }^{-1}\right)$ & $16978(3019)$ & $8032(493)$ \\
\hline
\end{tabular}

Differences in total phytoplankton biovolume reflected changes in taxon-specific biovolume between. the treatments. In particular, biovolume of the large species Peridinium willei was reduced in the presence of $D$. thomasi while biovolume of smaller species like Cryptomonas ovata, Oocystis lacustris, and flagellates increased. Calculating biovolume-weighted average phytoplankter volume $\left(P V, \mu \mathrm{m}^{3}\right.$ cell $\left.^{-1}\right)$ for each treatment indicated that additions of $D$. thomasi caused phytoplankter mean cell volume to decrease significantly relative to control treatments (Table 2). Flagellates were quantified without regard to trophic strategy in this experiment; therefore, MMFs (mixed microflagellates) are likely to represent a mix of autotrophic, heterotrophic, and mixotrophic flagellates. We assume that flagellates with different trophic strategies serve equally well as prey items for ciliates. We assume also that these 3 trophic strategies maintain relatively stable proportions in the flagellate category in the 2 treatments.

Increases in phytoplankton biomass in the Diacyclops thomasi treatment were probably due to decreased ciliate abundances since phytoplankton biovolume was strongly and negatively related to ciliate abundance $\left(p<0.005, r^{2}=0.81\right.$; Fig. 1). Thus, indirect effects of $D$. thomasi cascaded to the level of the phytoplankton. These increases in phytoplankton biomass, as indicated by chl a concentrations and biovolume, are consistent with our prediction that $D$. thomasi predation would result in increased phytoplankton biomass as suggested by the observations of Elser et al. (1995). However, as noted above, overall rates of microconsumer grazing at the end of the experiment did not differ between treatments.

Maximum growth capacity of the phytoplankton was significantly higher in treat- 
Table 3. Phytoplankton taxa present in treatments with (w/) and without (w/o) added Diacyclops thomasi. Values shown are mean biovolume $\left(\mu \mathrm{m}^{3} \mathrm{ml}^{-1}\right)$ and standard error for both treatments. Also shown is the contribution each species makes to the total phytoplankton biovolume ("p $<0.05)$

\begin{tabular}{|c|c|c|c|c|c|c|}
\hline \multirow{2}{*}{$\begin{array}{l}\text { Species } \\
\text { Aphanocapsa delicatıssima }\end{array}$} & \multicolumn{2}{|c|}{ Biovolume $w / 0$} & \multirow{2}{*}{$\frac{\% \text { of total }}{0.1}$} & \multicolumn{2}{|c|}{ Biovolume w/ } & \multirow{2}{*}{$\frac{\% \text { of tota }}{0.1}$} \\
\hline & 180 & (4) & & 240 & $(44)$ & \\
\hline Aphanocapsa elachista & 8610 & $(2660)$ & 4.8 & 6930 & (1157) & 3.1 \\
\hline Chroococcus limneticus & 18958 & $(972)$ & 9.4 & 21617 & (2017) & 10.1 \\
\hline Cosmarium bioculatum & 6305 & $(3006)$ & 3.8 & 3685 & (1355) & 1.7 \\
\hline Cryptomonas ovata & 16924 & $(5911)$ & 7.6 & 44208 & $(10778)$ & 19.4 \\
\hline Cyclotella stelligera & 72 & (43) & 0.0 & 136 & (75) & 0.1 \\
\hline Dinobryon bavaricum & 2223 & (519) & 1.1 & 1872 & $(427)$ & 0.9 \\
\hline Elakothrix gelatinosa & 36 & (15) & 0.0 & 33 & (8) & 0.0 \\
\hline Gleocystis sp. & 6961 & $(1119)$ & 3.5 & 7253 & (1023) & 3.4 \\
\hline Oocystis lacustris & 19664 & $(3352)$ & 9.2 & 34894 & $(5676)$ & 15.8 \\
\hline Peridinium willei & 115519 & $(24627)$ & 52.8 & 68906 & $(2340)$ & 31.5 \\
\hline Quadrigula lacustris & 732 & $(356)$ & 0.3 & 1755 & $(586)$ & 0.8 \\
\hline Rhodomonas minuta & 206 & $(23)$ & 0.1 & 233 & $(40)$ & 0.1 \\
\hline Closterium sp. & 6 & (3) & 0.0 & 16 & (2) & $0.0^{\circ}$ \\
\hline Flagellates & 14400 & $(2789)$ & 7.2 & 28632 & (3331) & $13.2^{\circ}$ \\
\hline Total & 210795 & $(25381)$ & & 220410 & (13523) & - \\
\hline
\end{tabular}

ments with Diacyclops thomasi ( $\mathrm{p}=0.009$; Table 2), suggesting a shift in the algal assemblage towards taxa with high growth potential. This observation is consistent with the decrease in mean algal size ( $P V$; Table 2) and increases in the relative contribution of microflagellates (Table 3) that we observed in the presence of D. thomasi.

Indirect effects of Diacyclops thomasi also appeared to propagate to the bacterioplankton. While dilution gradient experiments revealed no effect of $D$. thomasi on microconsumer grazing rates on bacteria or bacterial $\mu_{\text {max }}$ (Table $2 ; p=0.28$ and $p=0.36$, respectively), bacterial abundance was significantly higher in treatments with $D$. thomasi relative to controls $(p<0.01$; Table 2).

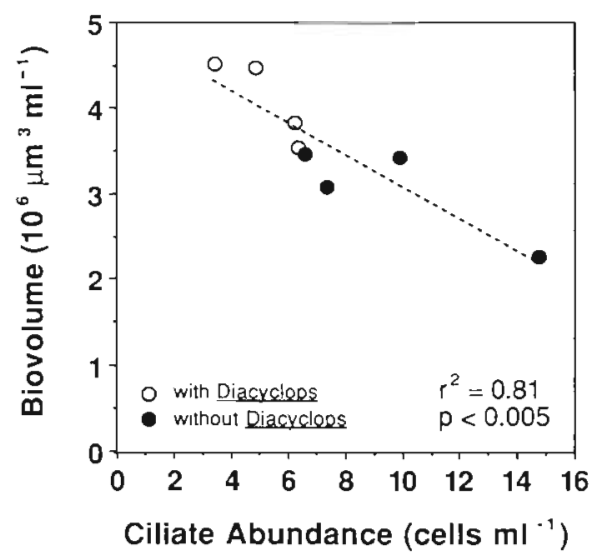

Fig. 1. Relationship between ciliate abundance and phytoplankton biovolume across all experimental treatments. The line was fit using least squares regression

\section{DISCUSSION}

In this experiment we exposed microplankton to a cyclopoid predator, Diacyclops thomasi, to test hypotheses regarding the causes of increased PPr and reduced water transparency in Castle Lake following a whole-lake food web manipulation that produced major increases in $D$. thomasi abundance (Elser et al. 1995). We predicted that $D$. thomasi would lower microconsumer grazing rates on phytoplankton and bacteria, leading to increases in algal and bacterial biomass in an unconditioned plankton community. Our data show that effects of predation by $D$. thomasi cascaded down through ciliates, phytoplankton, and possibly to bacteria. Ciliate abundances, especially oligotrichs and haptorids, were greatly reduced by cyclopoid predation. These results are consistent with other experiments in this system (Brett et al. 1994, Wiackowski et al. 1994). This reduction in microconsumers apparently altered the grazing regime on phytoplankton and altered primary producer community structure in favor of smaller, faster-growing species. Bacterial abundances were also affected by $D$. thomasi. Overall our data support the hypothesis that $D$. thomasi substantively alters microconsumer impacts on phytoplankton and microbial food webs in a way consistent with observed changes in Castle Lake following a food web manipulation that produced a substantial increase in $D$. thomasi. Thus, the mechanisms proposed by Elser et al. (1995) to explain changes in food web structure, PPr, and water transparency in Castle Lake appear valid.

In our experiment, increases in Diacyclops thomasi significantly reduced abundances in 2 species and 
marginally in 5 species of the 9 ciliate species present, resulting in a $50 \%$ decrease in total abundance. The large effects of $D$. thomasi on ciliate abundance found in this study agree with the results of other studies examining effects of cyclopoid predation on ciliates (Archbold \& Berger 1985, Wiackowski et al. 1994, Brett et al. 1995, Wickham 1995a). However, our data must be interpreted with caution for several reasons. Screening the initial water to remove smaller metazooplankton also removed nearly all of the rotifers. Removing rotifers thus also removed alternative prey for $D$. thomasi, which would tend to magnify the effects of $D$. thomasi on ciliates. Removing rotifers also reduces a potential source of predation on ciliates (Gilbert \& Jack 1993). Finally, many rotifers compete with ciliates for nanoplankton and removing rotifers may release ciliates from this competitive pressure. In short, it is difficult to say how these results would have changed with the inclusion of rotifers. Screening of initial water from Castle Lake in Brett et al.'s (1994) study failed to remove the rotifer Polyarthra vulgaris. Despite the inclusion of this alternative prey, there were still significant reductions in ciliate abundances in their experiments. Thus the exclusion of rotifers in our study does not appreciably detract from our conclusion that $D$. thomasi significantly reduces ciliate abundances. Additionally, we do not feel that screening our initial water compromised our results since rotifers were rare in Cliff Lake at the time of our experiments (D. Dobberfuhl pers. obs.).

Copepod preferences for large ciliates observed in other studies (Burns \& Gilbert 1993, Nielsen \& Kiørboe 1994) were not clearly evident in our study, as Diacy. clops thomasi had pronounced effects on ciliates $>17000 \mu^{3}$ in cell size (Strobilidium sp. and Strobilidium viridae) as well as ciliates $-5000 \mu \mathrm{m}^{3}$ (Urotricha farcta and Mesodinium sp.; Table 1). In contrast, an earlier study performed in Castle Lake found that $D$. thomasi had the greatest effect on the large oligotrichs Strobilidium $\mathrm{sp}$. and $S$. viridae and a somewhat reduced effect on the smaller $U$. farcta and Mesodinium sp. (Wiackowski et al. 1994). This size-specific effect agrees with earlier studies that have found predation rate to be positively correlated with ciliate size (Stoecker \& Egloff 1987, Burns \& Gilbert 1993). Lack of size-preference in our study may be related to low densities of larger ciliate species in the initial community.

Given the large direct effects of Diacyclops thomasi on ciliates, large indirect changes in lower trophic levels would also be expected. Our data indicate that indirect effects of $D$. thomasi on phytoplankton did occur (Tables 2 \& 3), consistent with previous evidence demonstrating that ciliates can efficiently graze phytoplankton (Goulder 1972, Heinbokel \& Beers 1979), nanoplanktonic chlorophytes (Beaver \& Crisman 1990), and heterotrophic nanoflagellates (Weisse 1991, Sanders et al. 1994). In our study, there was a strong negative relationship between ciliate abundance and algal biomass (Fig. 1).

While it is likely that ciliate herbivory caused much of the reduction in phytoplankton biomass that we observed in the no-Diacyclops treatment, the effects of nutrient recycling and rotifer exclusion must also be considered. For example, it is possible that recycling by $D$. thomasi may have contributed to greater phytoplankton biomass in the Diacyclops treatment. If nutrient recycling by $D$. thomasi had a large effect on phytoplankton then chl $a$ in the $D$. thomasi treatments should have been even higher than in the initial oligotrophic water However, chl a concentrations in the initial Cliff Lake water $\left(5 \mu \mathrm{g} \mathrm{l}^{-1}\right)$ were higher than in either the experimental or control containers at the end of the experiment and thus this possibility seems unlikely. Rotifer exclusion may also have affected phytoplankton biomass. If we had included rotifers, which efficiently prey on nanoplankton (Sanders \& Wickham 1993, Sanders et al. 1994), we might have actually seen a greater difference in phytoplankton biomass between the treatments, depending on the relative grazing rates of $D$. thomasi on a mixed assemblage of rotifers and ciliates. Therefore, our data may underestimate the indirect effects of $D$. thomasi on phytoplankton in situations where rotifers are common.

Indirect effects of Diacyclops thomasi on bacterioplankton appeared to increase bacterial abundance, as with phytoplankton (Table 2). This could be due to either decreased bacterial grazing or increased substrate availability in the Diacyclops treatments. The grazing rate on bacteria was not significantly different between the 2 treatments, arguing against top-down changes (Table 2). However, ciliate abundances and flagellate abundances appeared to be negatively and positively related to bacterial abundance, although not significantly (Fig. 2A and $\mathrm{B}$, respectively). It is more likely that increased bacterial densities changed in response to changes in resource availability. In our experiment, bacterial density was significantly correlated with chl a concentration (Fig. 3) as in other studies (Bird \& Kalff 1984, Scavia et al. 1986, Shortreed \& Stockner 1986, Lubnow 1992). Bacteria in oligotrophic systems like Cliff and Castle Lakes may be controlled by the availability of resources rather than by grazing (Pace \& Funke 1991, Pace 1993). Additionally, dead $D$. thomasi may have contributed to bacterial resources, although decomposition of dead individuals appeared negligible. Finally, recycling or sloppy feeding may have released nutrients to enhance bacterial production. However, bacterial abundances in both $D$ 

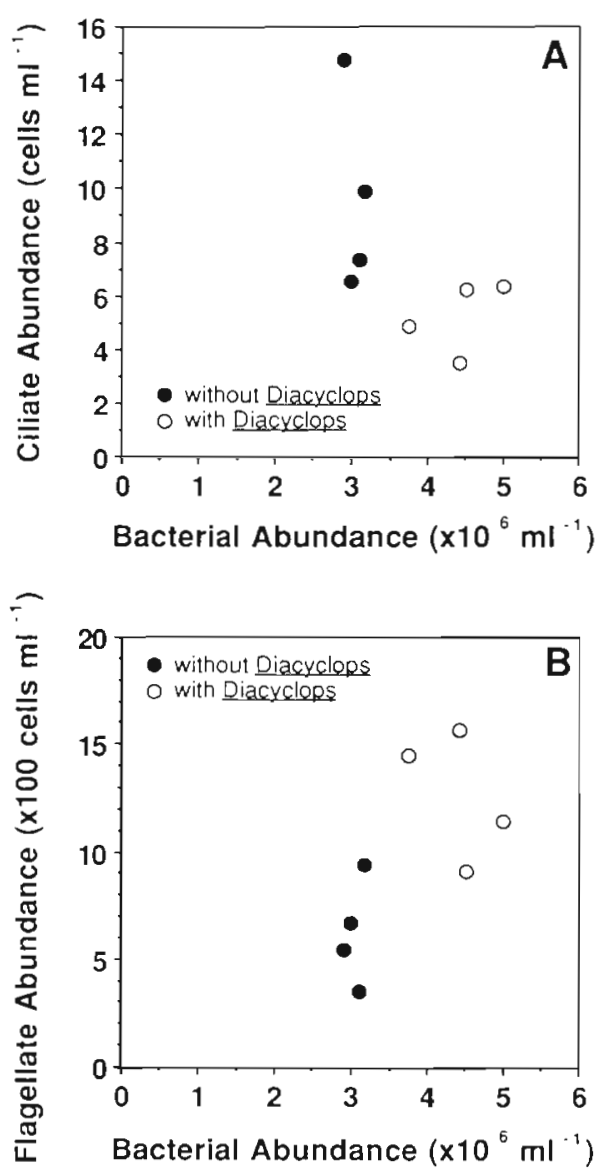

Fig. 2. Bacterial abundance versus (A) ciliate abundance and (B) flagellate abundance in enclosures with and without Diacyclops thomasi at the end of the $10 \mathrm{~d}$ incubation. Bars represent \pm 1 SE

thomasi and control treatments were lower than in initial Cliff Lake water, an observation that argues against an increase in substrate availability in the experimental enclosures.

Originally, we predicted that the addilion of Diacyclops thomasi would decrease microconsumer grazing rates on phytoplankton and bacteria. However, we did not see the predicted changes in microconsumer grazing rates (Table 2). Nonetheless, there were significant changes in both phytoplankton and bacterial biomass. It may be possible that even small changes in microconsumer grazing rates on individual taxa, undetected by the Landry-Hassett method, caused these changes in the phytoplankton and bacterial biomass. Altering community composition of microconsumers may not appreciably change integrated grazing rates on phytoplankton or bacteria, but it may result in community shifts in phytoplankton and bacteria leading to increased biomass (i.e. increases in microflagellates). It is not clear how rotifers would have affected our estimates of microconsumer grazing rates. Nonetheless, it

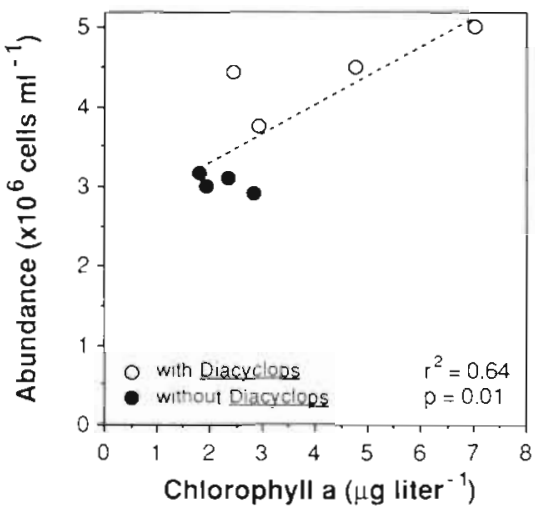

Fig. 3. Relationship between final bacterial abundance and chl a concentration across all experimental treatments. The line was fit using least squares regression

is still clear that $D$. thomasi can have large direct effects on ciliates and substantial indirect effects on lower trophic levels.

Introductions of predators, such as cyclopoids, may elicit indirect effects where the result of that indirect effect may depend on the state of the system. Prey communities that have been exposed to a predator for several generations would not respond as strongly to increased exposure of that predator as would a community that had not been exposed before. This may be why many of our results diverge from those of Brett et al. (1994), whose experiments closely matched ours in design. During the summer of 1991, Brett et al. (1994) added several dominant species of Castle Lake macrozooplankton, including Diacyclops thomasi, to enclosures containing screened Castle Lake water and incubated them for $8 \mathrm{~d}$. At the conclusion of their experiment they found no change in phytoplankton biovolume or bacterial abundance in response to manipulation of $D$. thomasi, in contrast to our results. However, they did find that $D$. thomasi significantly reduced ciliates, which agrees with our results. The important difference between the studies is that we began with a plankton community (from Cliff Lake) that had been exposed to very low levels of cyclopoid predation, whereas Brett et al. (1994) began with a plankton community that had already been exposed to cyclopoid predation for several years (Castle Lake). We would not expect substantial community changes in such a conditioned community. Our experiment was designed to examine the effect of $D$. thomasi introduction on a community unconditioned by cyclopoid predation. The contrasting results indicate that the introduction of $D$. thomasi into an unconditioned plankton community can cause changes in lower trophic levels where it might not in a conditioned community. Different processes may be responsible for the establishment 
versus the maintenance of community structure, as argued by Thorp (1986) Once $D$. thomasi acted to establish a new plankton community structure in Castle Lake, $D$. thomasi's role in short-term maintenance of that community structure may have been less important. In other words, Diacyclops predation may have acted to move the plankton community to a different state while other mechanisms serve to maintain that new state.

Our study indicates that introductions of Diacyclops thomasi into a plankton community unconditioned by cyclopoid predation can result in distinct changes in lower trophic levels. In our experiment, $D$. thomasi reduced ciliate abundances, producing indirect effects on phytoplankton biomass, community composition, and growth capacity as well as increased bacterial abundance. Increased abundances of small phytoplankton taxa and increased phytoplankton community growth capacity with addition of $D$. thomasi are consistent with observed increases in primary productivity and decreased water clarity in Castle Lake following the whole-lake food web manipulation. Thus our data support the hypothesis of Elser et al. (1995) that cyclopoid predation affected phytoplankton and bacteria in Castle Lake by altering the abundance and species composition of microconsumers, especially ciliates. In oligotrophic lakes such as Castle Lake, alterations at the top of the food web may be propagated to components at the bottom of the food web by a more complex set of mechanisms than originally incorporated within the framework of Cascading Trophic Interactions.

\section{LITERATURE CITED}

Adrian R (1991) Filtering and feeding rates of cyclopoid copepods feeding on phytoplankton. Hydrobiologia 210: $217-227$

Archbold HG, Berger J (1985) A qualitative assessment of some metazoan predators of Halteria grandinella a common freshwater ciliate. Hydrobiologia 126:97-102

Beaver JR, Crisman TL (1989) The role of ciliated protozoa in pelagic freshwater ecosystems. Microb Ecol 17 $111-136$

Beaver JR, Crisman TL (1990) Seasonality of planktonic ciliated protozoa in 20 subtropical Florida lakes of varying trophic state. Hydrobiologia 190:127-135

Bird DF, Kalff J (1984) Empirical relationships between bacterial abundance and chlorophyll concentration in fresh and marine waters. Can J Fish Aquat Sci 41:1015-1023

Brett MT, Wiackowski K, Lubnow FS, Mueller-Solger A, Elser JJ, Goldman CR (1994) Species-dependent effects of zooplankton on planktonic ecosystem processes in Castle Lake, California. Ecology 75:2243-2254

Burns CW, Gilbert JJ (1993) Predation on ciliates by freshwater calanoid copepods: rates of predation and relative vulnerabilities of prey. Freshwater Biol 30:377-393

Carpenter SR, Kitchell JF, Hodgson JR (1985) Cascading trophic interactions and lake productivity. BioSci 35: $634-639$
Carter JCH (1974) Life cycles of three limnetic copepods in a beaver pond. 3 Fish Res Board Can 31:421-434

Elser JJ (1992) Phytoplankton dynamics and the role of grazers in Castle Lake, California. Ecology 73:887-902

Elser JJ, Brett MT, Luecke C, Goldman CR (1995) Effects of food-web compensation after manipulation of Rainbow Trout in an oligotrophic lake. Ecology 76:52-69

Elser JJ, Frees DL (1995) Microconsumer grazing and sources of limiting nutrients for phytoplankton growth: application and complications of a nutrient deletion/ dilution gradient technique. Limnol Oceanogr 40 $1-16$

Gilbert JJ, Jack JD (1993) Rotifers as predators on small ciliates. Hydrobiologia 255/256:247-253

Goldman CR, De Amezaga E (1984) Primary productivity and precipitation at Castle Lake and Lake Tahoe during twenty-four years, 1959-1982. Verh Int Verein Limnol 22: $591-599$

Goulder R (1972) Grazing by the ciliated protozoan Loxodes magnus on the alga Scenedesmus in a eutrophic pond. Oikos 23:109-115

Hartmann HJ, Taleb H, Aleya L, Lair N (1993) Predation on ciliates by the suspension-feeding calanoid copepod Acanthodiaptomus denticornis. Can J Fish Aquat Sci 50: 1382-1393

Hein bokel JF, Beers JR (1979) Studies on the functional role of tintinnids in the Southern California Bight. III: Grazing impact of natural assemblages. Mar Biol 52:23-32

Hobbie JE, Daly J, Jasper S (1977) Use of Nucleopore filters for counting bacteria by fluorescence microscopy. Appl Environ Microbiol 33:1225-1228

Janik JJ (1988) Nutrient recycling in Castle Lake, California phytoplankton-zooplankton interactions. PhD thesis, University of California, Davis

Jonsson PR, Tiselius P $\{1990\}$ Feeding behaviour, prey detection and capture efficiency of the copepod Acartia tonsa feeding on planktonic ciliates. Mar Ecol Prog Ser 60: $35-44$

Landry MR, Hassett RP (1982) Estimating the grazing impact of marine microzooplankton. Mar Biol 67:283-288

Lubnow FS (1992) The influence of alternative deicing compounds on aquatic microbial ecosystems. PhD thesis, University of California, Davis

Marker AFH, Nusch EA, Rai H, Riemann B (1980) The measurement of photosynthetic pigments in freshwaters and standardization of methods: conclusions and recommendations. Ergeb Limnol 14:91-106

Nielsen TG, Kiørboe T (1994) Regulation of zooplankton biomass and production in a temperate coastal ecosystem. 2 . Ciliates. Limnol Oceanogr 39:508-519

Pace ML (1993) Heterotrophic microbial processes. In: Carpenter SR, Kitchell JF (eds) The trophic cascade in lakes. Cambride University Press, Cambridge, p 252-277

Pace ML. Funke E (1991) Regulation of planktonic microbial communities by nutrients and herbivores. Ecology 72 : $904-914$

Parsons TR, Maita Y, Lalli CM (1984) A manual of chemical and biological methods of seawater analysis. Pergamon, Elsford, NY

Sanders RW, Leeper DA, King CH, Porter KG (1994) Food web structure and zooplankton grazing impacts on photosynthetic and heterotrophic nanoplankton. Hydrobiologia 288: $167-181$

Sanders RW, Wickham SA (1993) Planktonic protists and metazoa: predation, food quality and population control. Mar Microb Food Webs 7:197-223 
Santer B (1993) Potential importance of algae in the diet of adult Cyclops vicinus. Freshwat Biol 30:269-278

Scavia D, Laird DA, Fahnenstiel GL (1986) Production of planktonic bacteria in Lake Michigan. Limnol Oceanogr 31:612-626

Shortreed KS, Stockner JG (1986) Trophic status of 19 subarctic lakes in the Yukon territories. Can J Fish Aquat Sci 43: $797-805$

Stemberger RS (1985) Prey selection by the copepod Diacyclops thomasi. Oecologia 65:492-497

Stoecker DK, Capuzzo JM (1990) Predation on protozoa: its importance to zooplankton. J Plankton Res 12:891-908

Stoecker DK, Egloff DA (1987) Predation by Acartia tonsa Dana on planktonic ciliates and rotifers. J Exp Mar Biol Ecol 110:53-68

Responsible Subject Editor: J. Dolan, Villefranche-sur-Mer, France
Thorp JH (1986) Two distinct roles for predators in freshwater assemblages. Oikos 47:75-82

Weisse T (1991) The annual cycle of heterotrophic freshwater nanoflagellates: role of bottom-up versus top-down control. J Plankton Res 13:167-185

Wiackowski K, Brett MT, Goldman CR (1994) Differential effects of zooplankton species on ciliate community structure. Limnol Oceanogr 39:486-492

Wickham SA (1995a) Trophic relations between cyclopoid copepods and ciliated protists: complex interactions link the microbial and classic food webs. Limnol Oceanogr 40: $1173-1181$

Wickharn SA (1995b) Cyclops predation on ciliates: speciesspecific differences and functional responses. J Plankton Res 17:1633-1646

Manuscript first received: February 20, 1996

Revised version accepted: October 28, 1996 